\title{
LITERASI INFORMASI KESEHATAN NIFAS IBU HAMIL BERSTATUS SOSIAL MENENGAH KE BAWAH
}

\author{
Post-Partum Health Information Literacy of Pregnant Women with \\ Middle-Low Social Status \\ Tito Yustiawan ${ }^{1}$, Nurhasmadiar Nandini ${ }^{2}$ \\ ${ }^{1}$ Fakultas Kesehatan Masyarakat, Universitas Airlangga, Indonesia \\ ${ }^{2}$ Fakultas Kesehatan Masyarakat, Universitas Diponegoro, Indonesia \\ E-mail: tito.yustiawan@gmail.com
}

\begin{abstract}
Background: Post-partum health information is hardly accessible to pregnant women. In fact, post-partum health literacy for pregnant mothers in relation to socio-economic factors allows the decline of post-partum morbidities. Aim: This research aimed to analyse the post-partum health information literacy of pregnant women with middlelow social status.

Method: This was a quantitative study by using a direct survey technique to assess respondents' information literacy about post-partum health. There were 79 pregnant women to take part in this study. They only completed their high school degree as their highest educational level, and their family income was less than Rp 2,000,000 (\$180) per month. This indicated that these participants are coming from middle-low social status. A selfdeveloped questionnaire was used in this study to be filled by respondents.

Results: Results showed that nearly half of respondents (44.1\%) found post-partum health information for their self-hygiene well-being after baby delivery process finished. Information accessed by pregnant women were elaborated from other people (66.1\%) like as parents, relatives, colleagues, or health officers. Most of the participants agreed to trust captured information (78\%), but there were only little use the information (11.9\%).

Conclusion: To summarize, the health information literacy of pregnant mothers with middle-low status was tenuously elaborated from other people, and most of them believed it. It is possible that information obtained from other people is incorrect, so pregnant mothers might use wrong information.
\end{abstract}

Keywords: health, information literacy, post-partum, pregnant women

\section{ABSTRAK}

Latar Belakang: Informasi kesehatan nifas masih sulit diakses oleh para ibu hamil. Faktanya literasi informasi kesehatan nifas untuk ibu hamil dan hubungannya dengan factor social dan ekonomi dapat menurunkan morbiditas post-partum.

Tujuan: Penelitian ini bertujuan untuk melakukan analisis deskriptif tentang literasi informasi kesehatan nifas para ibu hamil yang berasal dari status sosial menengah ke bawah.

Metode: Studi yang dilakukan adalah penelitian kuantitatif yang menggunakan teknik survei langsung ke responden. Sebanyak 79 orang ibu hamil yang setuju berpartisipasi sebagai responden dalam penelitian ini berlatar belakang pendidikan tidak lebih dari Sekolah Menengah Atas dengan penghasilan keluargatidak lebih dari Rp 2.000.000,- per bulan. Responden diminta mengisi kuesioner yang dikembangkan sendiri oleh peneliti. Hasil: Hasil penelitian menunjukkan sebagian responden $(44,1 \%)$ menyatakan mencari informasi kesehatan nifas tentang menjaga kebersihan diri (self-hygiene) setelah melahirkan. Informasi yang paling banyak diakses oleh ibu hamil didapatkan melalui orang lain $(66,1 \%)$ seperti orang tua, saudara, teman, atau petugas kesehatan. Sebagian besar responden menyatakan mempercayai informasi yang didapatkan (78\%). Namun, sedikit responden $(11,9 \%)$ menyatakan telah memanfaatkan seluruh informasi.

Kesimpulan: Kesimpulan dari penelitian ini adalah informasi kesehatan nifas yang cenderung diakses adalah tentang menjaga kebersihan diri yang didapatkan dari orang lain dan sebagian besar mempercayai informasi yang diperoleh. Ada kemungkinan informasi tentang kesehatan nifas yang diperoleh dari orang lain tidak benar sehingga para ibu hamil berisiko memanfaatkan informasi yang keliru.

Kata Kunci: ibu hamil, kesehatan, literasi informasi, nifas.

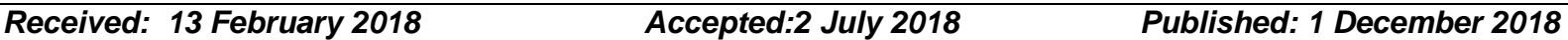

\section{PENDAHULUAN}

Kebutuhan terhadap informasi di kehidupan abad ke-21 semakin meningkat dan dianggap esensial. Informasi seringkali digunakan oleh manusia untuk mengambil keputusan termasuk di bidang kesehatan, baik oleh penyedia maupun pengguna pelayanan kesehatan. Penyedia pelayanan kesehatan dapat memanfaatkan informasi kesehatan untuk memberikan pelayanan kesehatan bermutu kepada pengguna. Sebaliknya, pengguna pelayanan kesehatan melakukan 
pencarian informasi kesehatan untuk meningkatkan pengetahuan serta wawasan tentang kesehatan.

Kebutuhan terhadap informasi kesehatan dapat disebabkan karena adanya isu atau masalah seperti salah satunya kesehatan ibu dan jumlah kematian anak. Isu kesehatan ibu dianggap penting karena dapat berdampak pada kesehatan kehamilan dan janin. Kondisi kehamilan dan janin yang sehat berdampak positif terhadap keselamatan ibu termasuk bayi saat persalinan. Kondisi kesehatan setelah persalinan (nifas) juga penting bagi ibu yang telah melahirkan. Oleh karena itu, kebutuhan informasi kesehatan nifas bagi para wanita hamil yang telah menjalani proses bersalin perlu didapatkan agar tidak salah dalam mencari, mengumpulkan, dan menganalisisnya.

Periode nifas adalah masa yang penting bagi kesehatan ibu. Pada masa nifas, dibutuhkan perawatan ekstra pada ibu dan bayi. Persepsi dan perilaku yang kurang tepat pada masa nifas dapat menyebabkan komplikasi dan membahayakan kesehatan dan keselamatan ibu (Missiriya, 2016). Komplikasi persalinan seringkali terjadi pada minggu pertama masa nifas. Komplikasi fatal yang umumnya terjadi seperti perdarahan, sepsis, eklamsia dapat menyebabkan kematian ibu pada masa nifas (Shah \& Pariyar, 2016).

Pada masa nifas, ibu seharusnya melakukan kunjungan nifas ke fasilitas kesehatan sebanyak minimal 3 kali setelah melahirkan. Kunjungan nifas bertujuan untuk memantau status kesehatan ibu dan bayi, melakukan pencegahan terhadap kemungkinan gangguan kesehatan ibu dan bayi, mendeteksi dini komplikasi atau masalah, dan menangani komplikasi atau masalah yang timbul dan mengganggu kesehatan ibu dan bayi (Kementerian Kesehatan Republik Indonesia, 2015). Kunjungan nifas di Indonesia pada umumnya rendah karena masih banyak ibu yang memiliki kepercayaan bahwa ibu nifas dilarang keluar rumah pada jangka waktu tertentu sehingga ibu terlambat melakukan pemeriksaan (Khafidzoh, et al., 2016).

Pendidikan kesehatan dan promosi kesehatan mengenai perawatan nifas sangat dibutuhkan khususnya bagi ibu dengan pendidikan rendah dan kondisi sosial ekonomi yang buruk. Penelitian di Pakistan menunjukkan bahwa kunjungan masa nifas ke pelayanan kesehatan sangat rendah. Mayoritas ibu tidak memahami pentingnya perawatan masa nifas sehingga tidak memiliki kesadaran untuk mencari informasi mengenai perawatan nifas.

Upaya seseorang untuk mencari, mengumpulkan, menganalisis, hingga menggunakan informasi disebut literasi informasi. Literasi informasi merupakan pilar utama dalam manajemen pengetahuan dalam kehidupan manusia di dunia dan berkaitan erat dengan pendidikan seseorang. Seseorang yang tidak memiliki kemampuan dan ketrampilan literasi informasi akan kesulitan untuk menemukan informasi yang dibutuhkan, menentukan kesahihan (kredibilitas dan akurasi) yang diperoleh, bahkan tidak tahu cara mengakses informasi yang benar (Mokhtar et al., 2004). Oleh karena itu, literasi informasi menjadi isu penting yang harus terus ditingkatkan termasuk di bidang kesehatan ibu dan anak (KIA).

Kesehatan ibu dan anak menjadi salah satu konsentrasi dunia bahkan status kesehatan sebuah negara pun ditentukan berdasarkan tingkat keberhasilan menurunkan angka kematian wanita saat hamil, melahirkan, dan nifas (post-partum). Isu tentang kesehatan ibu nifas masih kurang mendapat perhatian dari semua pihak bahkan cenderung diabaikan. Data penelitian tentang kematian pasca melahirkan di beberapa negara menunjukkan penyebab utama kematian adalah kelelahan atau keletihan. Prevalensi kematian pada masa dua bulan setelah melahirkan yang disebabkan fatigue or tiredness di negara Kanada dilaporkan terdapat $55 \%$ dan di negara Amerika Serikat sebanyak 76\% (Cheng, et al., 2006). Fenomena ini cukup mengejutkan karena terjadi di dua negara benua Amerika yang dapat dikatakan negara maju bahkan adi kuasa. Kejadian serupa dengan angka yang lebih besar sangat mungkin muncul di negara berkembang seperti di Indonesia.

Penelitian yang mengkaitkan kejadian post partum morbidities dengan literasi informasi jumlahnya masih minimal. Literasi informasi merupakan sebuah pendekatan yang paling tidak bisa digunakan untuk membangun pengetahuan dan menyelesaikan masalah (Mokhtar et al., 2004). Masalah kesehatan nifas seperti kejadian post partum morbidities seharusnya dapat diselesaikan dengan lebih meningkatkan literasi informasi khususnya pada ibu hamil. Problem yang juga penting untuk dicermati adalah faktor kemampuan sosial ekonomi yang dapat berdampak terhadap tingkat pendidikan dan pengetahuan seseorang. Oleh karena itu, penelitian ini bertujuan menilai literasi informasi pada ibu hamil pada kelas ekonomi menengah ke bawah tentang kesehatan informasi, khususnya informasi mengenai kesehatan nifas.

\section{METODE}

Penelitian yang dilakukan merupakan studi kuantitatif menggunakan pendekatan deskriptif melalui survei langsung (direct survey) kepada responden ibu hamil. Penelitian ini melakukan pengumpulan data secara cross-sectional dengan mengajukan sejumlah pertanyaan kepada responden tentang kebiasaan mencari informasi tentang kesehatan nifas (setelah melahirkan). Penelitian ini dilakukan selama enam minggu pada bulan Agustus - September 2016 di Kota Surabaya.

Responden yang terlibat dalam survei ini sebanyak 79 ibu hamil dengan kriteria inklusi sedang dalam kondisi hamil denganusia kehamilan minimal 32 minggu. Responden dalam penelitian ini adalah ibu hamil dengan tingkat penghasilan kurang dari Rp 2.000.000,- per bulan (setara dengan US\$ 200) dan tingkat pendidikan tertinggi sekolah menengah atas.

Data dikumpulkan melalui survei langsung secara door to door (dari rumah ke rumah) melalui wawancara kepada responden menggunakan daftar pertanyaan terstruktur. Para responden telah diminta menyatakankesediaannya untuk berpartisipasi dalam penelitian ini menggunakan pernyataan persetujuan (informed concent). 
Pertanyaan awal yang diajukan adalah persepsi responden tentang pentingnya informasi kesehatan nifas (setelah melahirkan) pada ibu hamil. Sebanyak 59 ibu hamil menyatakan informasi kesehatan nifas itu penting, sebaliknya 20 ibu hamil menyatakan tidak penting. Berdasarkan jawaban atas pertanyaan awal ini kemudian 59 ibu hamil ditanya lebih lanjut sesuai panduan wawancara dalam penelitian ini.

Pertanyaan yang diajukan kepada responden terkait dengan pengalaman kehamilan yang telah dilalui sampai saat ini. Pertimbangan mengajukan pertanyaan ini adalah pengalaman kehamilan kemungkinan mempunyai keterkaitan dengan cara mencari informasi. Pertanyaan berikut yang disampaikan kepada responden adalah bentuk informasi yang biasa dicari serta cara mengaksesnya. Pertanyaan lain yang dilontarkan adalah sikap responden dalam mempercayai informasi yang diperoleh serta aksi responden untuk mendistribusikan informasi yang didapatkan kepada orang lain. Data yang telah dikumpulkan selanjutnya dianalisis secara deskriptif untuk mengetahui distribusi jawaban yang diberikan responden saat survei. Penelitian yang dilakukan telah disetujui melalui uji laik etik penelitian oleh Komite Etik Penelitian Kesehatan di Fakultas Kesehatan Masyarakat Universitas Airlangga pada tanggal berdasarkan Surat Lolos Uji Etik Nomor: 396 KEPK.

\section{HASIL DAN PEMBAHASAN}

Aktivitas para ibu hamil dalam mencari informasi tentang kesehatan nifas dapat ditentukan oleh pengalaman kehamilan. Tabel 1 menunjukkan bentuk informasi kesehatan pada masa nifas (setelah melahirkan) yang dicari para ibu hamil berdasarkan kehamilan yang telah dialami. Hasil penelitian menunjukkan para ibu hamil lebih banyak mencari informasi pada masa kehamilan pertama. Selanjutnya, kebiasaan mencari informasi pada masa kehamilan kedua dan seterusnya cenderung semakin berkurang. Ibu yang sudah pernah melahirkan sebelumnya merasa telah memiliki pengalaman dan pengetahuan yang cukup sehingga sudah tidak perlu untuk mencari informasi mengenai kesehatan nifas.

Tabel 1. Pencarian Informasi Kesehatan Nifas Berdasarkan Pengalaman Kehamilan Ibu Hamil

\begin{tabular}{|c|c|c|c|c|c|c|c|c|c|c|}
\hline \multirow{3}{*}{$\begin{array}{c}\text { Informasi } \\
\text { Kesehatan Nifas } \\
\text { yang dicari }\end{array}$} & \multicolumn{10}{|c|}{ Pengalaman Kehamilan } \\
\hline & \multicolumn{2}{|c|}{ Pertama } & \multicolumn{2}{|c|}{ Kedua } & \multicolumn{2}{|c|}{ Ketiga } & \multicolumn{2}{|c|}{ Keempat } & \multicolumn{2}{|c|}{ Total } \\
\hline & $\mathbf{n}$ & $\%$ & $\mathbf{n}$ & $\%$ & $n$ & $\%$ & $n$ & $\%$ & $\mathrm{n}$ & $\%$ \\
\hline $\begin{array}{l}\text { Cara menjaga } \\
\text { kebersihan tubuh } \\
\text { setelah } \\
\text { melahirkan }\end{array}$ & 12 & 20,4 & 10 & 16,9 & 3 & 5,1 & 2 & 3,4 & 26 & 44,06 \\
\hline $\begin{array}{l}\text { Pemeriksaan } \\
\text { kesehatan rutin } \\
\text { untuk ibu setelah } \\
\text { melahirkan }\end{array}$ & 8 & 13,5 & 10 & 16,9 & 3 & 5,1 & 1 & 1,7 & 23 & 38,98 \\
\hline Masa (lama) nifas & 3 & 5,1 & 0 & 0,0 & 0 & 0,0 & 1 & 1,7 & 4 & 6,8 \\
\hline $\begin{array}{l}\text { Kelainan yang } \\
\text { bisa terjadi pada } \\
\text { masa nifas }\end{array}$ & 2 & 3,4 & 0 & 0,0 & 1 & 1,7 & 0 & 0,0 & 3 & 5,1 \\
\hline $\begin{array}{l}\text { Penggunaan } \\
\text { kontrasepsi }\end{array}$ & 0 & 0,0 & 1 & 1,7 & 0 & 0,0 & 0 & 0,0 & 1 & 1,7 \\
\hline Lainnya & 0 & 0,0 & 0 & 0,0 & 2 & 3,4 & 0 & 0,0 & 2 & 3,4 \\
\hline TOTAL & 25 & 42,4 & 21 & 35,6 & 9 & 15,3 & 4 & 6,8 & 59 & 100,0 \\
\hline
\end{tabular}
mencari informasi tentang mekanisme melindungi kebersihan tubuh $(44,06 \%)$, dan $20,4 \%$ diantaranya adalah yang baru merasakan pengalaman kehamilan pertama. Kegiatan ini sedikit berbeda dengan perempuan yang dalam kondisi hamil untuk kedua kalinya yang cenderung mencari wawasan tentang bentuk dan jenis pemeriksaan kesehatan rutin untuk dirinya (16,9\%).

Pada pengalaman ibu pada kehamilan ketiga dan keempat, kegiatan mencari informasi tentang menjaga kesehatan dan memeriksakan kesehatan rutin masih dilakukan namun jumlahnya sangat sedikit. Selain itu para responden ibu hamil juga mencari informasi kesehatan nifas lainnya seperti lamanya masa nifas (6,8\%), kelainan (penyakit atau masalah kesehatan) yang dapat terjadi pada masa
Penelitian yang dilakukan Khafidzoh, et.al. (2016) menunjukkan bahwa pada umumnya, ibu masih menganggap perawatan masa nifas dilakukan berdasarkan pengalaman. Penelitian lain juga menyatakan bahwa ibu yang sudah pernah

memiliki anak sebelumnya merasa sudah memiliki pengetahuan dan pengalaman yang cukup dan mengenai perawatan nifas sehingga berdampak pada keputusan ibu untuk melakukan pencarian informasi (Ekawati \& Haniah, 2017).

Mekanisme dalam mencari informasi dapat dikaitkan dengan sumber informasi yang diakses oleh ibu hamil. Hasil penelitian ini mendapatkan sumber informasi yang diakses para responden utamanya hanyadua yaitu orang lain dan internet. Tabel 2 memperlihatkan bahwa lebih dari sebagian 
responden $(66,1 \%)$ yang diwawancara cenderung mencari informasi dari sumber yang memungkinkan terjadinya komunikasi dua arah yaitu orang lain. Berdasarkan hasil wawancara sejumlah orang yang menjadi sumber informasi bagi ibu hamil adalah petugas kesehatan (dokter, bidan, perawat), orang tua, saudara, atau teman. Hasil penelitian menunjukkan para ibu hamil cenderung tidak mengakses informasi tentang kesehatan nifas melalui internet.

Hasil penelitian pada Tabel 2 menunjukkan kegiatan pencarian informasi yang tidak berbeda dengan Tabel 1. Informasi yang paling banyak diakses oleh ibu hamil melalui orang lain adalah tentang pemeriksaan kesehatan rutin setelah melahirkan (30,5\%). Pencarian informasi kesehatan nifas melalui internet yang paling banyak dilakukan responden adalah untuk mengetahui cara mempertahankan self-hygiene setelah persalinan $(16,9 \%)$. Responden juga memanfaatkan sumber informasi lain (buku, majalah) untuk menambah pengetahuan tentang kelainan yang berpotensi terjadi setelah melahirkan, tetapi jumlahnya sangat sedikit.

Tabel 2. Pencarian informasi dan akses sumber informasi tentang kesehatan nifas

\begin{tabular}{|c|c|c|c|c|c|c|c|c|}
\hline \multirow{3}{*}{$\begin{array}{c}\text { Informasi } \\
\text { Kesehatan Nifas } \\
\text { yang dicari }\end{array}$} & \multicolumn{8}{|c|}{ Akses Sumber Informasi } \\
\hline & \multicolumn{2}{|c|}{ Orang lain } & \multicolumn{2}{|c|}{ Internet } & \multicolumn{2}{|c|}{$\begin{array}{c}\text { Lainnya } \\
\text { (buku, majalah) }\end{array}$} & \multicolumn{2}{|c|}{ Total } \\
\hline & $n$ & $\%$ & $n$ & $\%$ & $\mathbf{n}$ & $\%$ & $n$ & $\%$ \\
\hline $\begin{array}{l}\text { Cara menjaga } \\
\text { kebersihan tubuh } \\
\text { pasca melahirkan }\end{array}$ & 15 & 25,4 & 10 & 16,9 & 1 & 1,7 & 26 & 44,1 \\
\hline $\begin{array}{l}\text { Pemeriksaan } \\
\text { kesehatan rutin } \\
\text { untuk ibu nifas }\end{array}$ & 18 & 30,5 & 5 & 8,5 & 0 & 0,0 & 23 & 39,0 \\
\hline Masa (lama) nifas & 3 & 5,1 & 1 & 1,7 & 0 & 0,0 & 4 & 6,8 \\
\hline $\begin{array}{l}\text { Kelainan yang bisa } \\
\text { terjadi pada masa } \\
\text { nifas }\end{array}$ & 2 & 3,4 & 0 & 0,0 & 1 & 1,7 & 3 & 5,1 \\
\hline $\begin{array}{l}\text { Penggunaan } \\
\text { kontrasepsi }\end{array}$ & 1 & 1,7 & 1 & 1,7 & 0 & 0,0 & 2 & 3,4 \\
\hline Lainnya & 0 & 0,0 & 1 & 1,7 & 0 & 0,0 & 1 & 1,7 \\
\hline TOTAL & 39 & 66,1 & 18 & 30,5 & 2 & 3,4 & 59 & 100,0 \\
\hline
\end{tabular}

Tabel 3. Pemanfaatan informasi kesehatan nifas berdasarkan persepsi responden

\begin{tabular}{|c|c|c|c|c|c|c|c|c|c|c|}
\hline \multirow{3}{*}{$\begin{array}{l}\text { Persepsi terhadap } \\
\text { Informasi }\end{array}$} & \multicolumn{10}{|c|}{ Memanfaatkan Informasi } \\
\hline & \multicolumn{2}{|c|}{$\begin{array}{c}\text { Sebagian } \\
\text { Kecil }\end{array}$} & \multicolumn{2}{|c|}{ Sebagian } & \multicolumn{2}{|c|}{$\begin{array}{c}\text { Sebagian } \\
\text { Besar }\end{array}$} & \multicolumn{2}{|c|}{ Seluruhnya } & \multicolumn{2}{|c|}{ Total } \\
\hline & $\mathbf{n}$ & $\%$ & $\mathbf{n}$ & $\%$ & $\mathbf{n}$ & $\%$ & $\mathrm{n}$ & $\%$ & $\mathbf{n}$ & $\%$ \\
\hline Mempercayai & 10 & 16,9 & 19 & 32,2 & 11 & 18,6 & 6 & 10,2 & 46 & 78,0 \\
\hline Tidak Mempercayai & 4 & 6,8 & 4 & 6,8 & 4 & 6,8 & 1 & 1,7 & 13 & 22,0 \\
\hline TOTAL & 14 & 23,7 & 33 & 39,0 & 15 & 25,4 & 7 & 11,9 & 59 & 100,0 \\
\hline
\end{tabular}

\section{Pemanfaatan Informasi Kesehatan Nifas Menurut Persepsi Responden}

Persepsi seseorang terhadap sesuatu yang diperoleh dapat menentukan tindakan selanjutnya. Pemanfaatan informasi kesehatan nifas dapat ditentukan oleh persepsi ibu hamil untuk mempercayai informasi yang diperoleh atau sebaliknya dan dapat mempengaruhi keputusan ibu untuk melakukan kunjungan nifas. Tingkat pemanfaatan informasi yang diterima responden dapat dibedakan dan disajikan dalam Tabel 3 .

Hasil penelitian pada Tabel 3 memperlihatkan bahwa sebagian besar responden menyatakan mempercayai informasi yang didapatkan (78,0\%), meskipun ibu hamil yang menyatakan telah memanfaatkan seluruh informasi yang didapat jumlahnya tidak banyak (11,9\%). Responden pun ternyata tetap memanfaatkan informasi yang didapatkan meski ada sebagian kecil dari ibu hamil menyatakan tidak mempercayai informasi yang telah diakses (22,0\%). Jawaban responden juga menunjukkan adanya keraguan untuk mempercayai informasi yang diperoleh sehingga lebih dari separuh kelompok responden yang menyatakan "memanfaatkan sebagian" $(39,0 \%)$ dan "memanfaatkan sebagian besar" $(25,4 \%)$ informasi yang didapatkan.

Persepsi ibu dan pemanfaatan informasi kesehatan juga dipengaruhi oleh persepsi dari keluarga terdekat seperti suami, orang tua atau mertua. Beberapa ibu menyatakan bahwa ibu mempercayai informasi mengenai kesehatan nifas. Namun masih merasa ragu untuk memanfaatkan informasi tersebut secara keseluruhan karena pengaruh dari keluarga terdekat. Hal ini ditunjukkan dari Tabel 3 yang menyatakan bahwa dari keseluruhan ibu yang mempercayai informasi kesehatan, hanya sebagian kecil $(10,2 \%)$ yang memanfaatkan keseluruhan informasi tersebut. Penelitian menunjukkan terdapat hubungan antara 
dukungan keluarga dengan perilaku ibu untuk memanfaatkan pelayanan nifas (Rahayu, et al., 2016).

\section{Informasi Kesehatan Nifas yang Paling Sering Dicari}

Kesehatan merupakan kebutuhan dasar yang harus dipenuhi dan disediakan kepada setiap orang. Kesehatan didefinisikan sebagai kondisi atau status yang menunjukkan seseorang tidak hanya terbebas dari rasa sakit serta tidak nyaman, bahkan lebih luas lagi ditentukan berdasarkan tingkat produktivitas dan kesejahteraan. Setiap ibu yang dalam kondisi hamil akan mengalami kekhawatiran tentang kondisi kesehatannya termasuk saat dirinya melahirkan kemudian memasuki masa nifas. Oleh karena itu, para ibu hamil mencari informasi untuk memperoleh wawasan dan pengetahuan.

Pencarian informasi kesehatan nifas ternyata menunjukkan pola yang relatif linier, artinya semakin bertambah jumlah proses persalinan yang telah dialami para responden maka semakin sedikit frekuensi untuk mencari informasi. Hasil penelitian pada Tabel 1 menunjukkan para responden lebihkonsisten untuk mencari informasi kesehatan nifas tentang kebersihan dan kesehatan, durasi (lama) nifas meski sudah bersalin beberapa kali. Pencarian informasi kesehatan nifas yang terkait dengan durasi dan komplikasi cenderung dibutuhkan pada para responden yang mengalami proses bersalin untuk pertama kali.

Hasil yang ditampilkan pada Tabel 2 menunjukkan hampir sebagian responden (44,1\%) menyatakan mencari informasi tentang menjaga kebersihan diri (self-hygiene) setelah melahirkan. Kondisi ini dapat dikatakan wajar karena setiap perempuan yang melahirkan merasa "kotor" karena banyak berkeringat atau mengeluarkan darah saat proses bersalin. Selain cara mempertahankan selfhygiene, para responden $(39,0 \%)$ menyatakan juga membutuhkan informasi untuk pemeriksaan kesehatan rutin pada masa nifas. Kedua temuan ini menunjukkan bahwa para responden tetap mempunyai keinginan untuk menjaga kondisi kebersihan dan kesehatan dirinya, sehingga berupaya mencari ke beberapa sumber informasi. Hasil tersebut sesuai dengan penelitian di Nepal yang menyatakan bahwa informasi yang paling banyak dicari oleh ibu nifas adalah mengenai kebersihan diri khususnya perineal hygiene (Shah \& Pariyar, 2016).

Informasi mengenai kebersihan diri sangat penting bagi kesehatan ibu pada masa nifas. Kebersihan diri khusunya pada area perineal perlu perhatian khusus karena area perineal memiliki risiko ditumbuhi organisme pathogenicyang membahayakan kesehatan dan dapat menyebabkan kematian ibu (Missiriya, 2016). Sumber informasi kesehatan nifas yang paling banyak diakses para responden $(66,1 \%)$ adalah melalui orang lain seperti orang tua (terutama ibu), petugas kesehatan, saudara atau teman. Sumber informasi selain petugas kesehatan bisa dianggap tidak kompeten karena kegiatan penyampaian informasi seperti ini dapat dilakukan di lingkungan yang tidak formal atau tidak ilmiah seperti bercengkrama saat bertemu. Kegiatan penyampaian informasi kesehatan sebenarnya dapat dikategorikan konsultasi kesehatan dan seharusnya dilakukan oleh seseorang yang mempunyai kompetensi baik pengetahuan, kemampuan, keterampilan maupun legal.

Beberapa ibu menyatakan telah membaca informasi mengenai kesehatan nifas di Buku KIA. Namun, sebagian besar ibu hanya menggunakan Buku KIA sebagai sarana pencatatan hasil kunjungan pemeriksaan antenatal. Buku KIA (Kesehatan lbu dan Anak) adalah buku yang berisi catatan kesehatan ibu hamil, bersalin hingga masa nifas dan catatan kesehatan anak sejak bayi baru lahir hingga usia 6 tahun serta terdapat berbagai informasi cara memelihara dan merawat kesehatan ibu dan anak (Kementerian Kesehatan Republik Indonesia, 2015). Oleh karena itu, dibutuhkan penjelasan lebih lanjut dan dorongan agar ibu memanfaatkan dan membaca Buku KIA secara keseluruhan.

\section{Internet sebagai Sumber Informasi Kesehatan Nifas}

Akses terhadap informasi kesehatan berperan dalam meningkatkan pengetahuan kesehatan, mengambil keputusan kesehatan, dan meminta pelayanan kesehatan (Sulaeman, et al., 2015). Hasil penelitian menunjukkan bahwa hanya sebagian kecil responden $(30,5 \%)$ yang mengakses internet untuk mencari informasi kesehatan nifas. Hasil ini menunjukkan bahwa sudah ada ketertarikan dari kelompok sosial menengah ke bawah untuk mencari informasi dari sumber yang dapat diragukan kebenarannya. Mesin pencari dan media sosial daring adalah salah satu alat yang popular untuk mencari dan berbagi informasi kesehatan. Penelitian menunjukkan bahwa masyarakat menyadari bahwa informasi yang didapatkan dari media sosial dan mesin pencari di internet dapat berbeda dan mempengaruhi privasi seseorang, namun mereka tetap mencoba mencari informasi mengenai berbagai hal terkait kesehatan di internet (De Choudhury, et al., 2014).

Tersedianya akses terhadap internet mempengaruhi perilaku pencarian informasi kesehatan seseorang. Penelitian menunjukkan bahwa kemudahan akses terhadap layanan internet dan kepercayaan terhadap informasi kesehatan daring dapat mempengaruhi perilaku seseorang terkait frekuensi pencarian inormasi kesehatan daring, keragaman penggunaan informasi kesehatan daring dan prefrensi internet untuk pencarian awal (Xiao, et al., 2014). Penelitian ini belum menggali lebih dalam situs di internet yang biasa diakses untuk mencari informasi kesehatan nifas. Ada kemungkinan para responden yang mengakses informasi kesehatan nifas di internet berasal dari sumber yang tidak ilmiah atau tidak akademis, seperti artikel lepas atau blog.

Penggunaan perangkat teknologi informasi seperti gawai (gadget) untuk mengakses informasi di negara kurang berkembang di Afrika menunjukkan hasil yang tidak terlalu signifikan (Chilukuri, et al., 2015). Laporan Intel Corporation, Dalberg Global Development Advisors, dan Globescan yang berjudul "Women and the Web" menyampaikan bahwa wanita di India yang 
mengakses internet hanya $8 \%$ dari total populasi (Dalberg, 2012). Beberapa penyebab wanita tidak mengakses dikaitkan dengan faktor ekonomi (kemampuan membayar), tidak tahu caranya, serta rendahnya pengetahuan tentang bahasa Inggris (Chilukuri, et al., 2015). Perlu dipahami bahwa kebanyakan informasi kesehatan nifas (post partum maternity) ditulis dalam jurnal ilmiah berbahasa Inggris. Faktor bahasa Inggris ini dapat menjadi penghambat bagi responden untuk mempunyai ketertarikan membacanya apalagi memahami isinya.

Kondisi ini seharusnya perlu segera diintervensi oleh pemerintah sesegera mungkin menyediakan portal atau situs khusus yang memberikan informasi tentang kesehatan nifas berbahasa nasional (Bahasa Indonesia) atau dalam bahasa daerah. Karakteristik negara Indonesia yang terdiri dari bermacam-macam suku dan bahasa perlu mendapat perhatian khusus, apalagi masih ada penduduk yang tinggal di daerah terpencil. Masyarakat yang tinggal di daerah terpencil, tertinggal, atau di daerah perbatasan dapat mengalami kesulitan mengakses pendidikan yang standar dan berkualitas termasuk mempelajari bahasa, baik bahasa nasional maupun bahasa asing. Akibat dari kondisi ini adalah kelompok masyarakat tersebut akan lebih nyaman menggunakan bahasa daerah (lokal) daripada bahasa nasional sebagai alat komunikasi seharihari.

\section{Rasa Percaya dan Pemanfaatan Informasi Kesehatan Nifas}

Hasil penelitian menunjukkan perilaku para ibu hamil dalam memanfaatkan informasi kesehatan nifas. Lebih dari tiga perempat responden penelitian ini menyatakan mempercayai informasi yang didapatkan, namun tidak semua memanfaatkan informasi yang didapatkan. Kerangka Health Belief Model menyebutkan salah satu variabel penting yang menentukan likelihood of action seseorang adalah adanya cue of action. Seseorang membutuhkan input informasi sebagai petunjuk atau arah dalam menentukan tindakan serta mengambil keputusan. Input informasi diperoleh melalui berbagai media yang dapat diakses oleh seseorang.

Studi ini telah menunjukkan bahwa perilaku pencarian informasi kesehatan nifas pada ibu hamil dengan strata ekonomi menengah ke bawah cenderung bergantung pada orang lain, bukan internet serta bahan bacaan (majalah atau buku). Sumber informasi tentang kesehatan nifas yang paling sering diakses oleh ibu hamil adalah orang lain (petugas kesehatan, orang tua, saudara, teman). Kecenderungan para ibu hamil mencari informasi kesehatan nifas dari petugas kesehatan relatif normal dan wajar, mengingat kompetensi yang dimiliki. Namun, para ibu hamil juga mencari dari orang lain yang tidak diketahui tingkat kompetensinya. Perilaku pencarian informasi bukan dari orang yang kompeten berpotensi mengakibatkan ibu hamil memperoleh informasi yang tidak valid sehingga kualitas informasinya pun lemah.

Informasi yang diperoleh oleh pengguna dapat bersifat inaccesible, insecure, hardly retrievable, difficult to aggregate, errors in transformation (Haug, et al., 2011). Dengan demikian, para ibu hamil pun akan mengalami kesulitan untuk memperoleh kembali, kalau pun bisa akan membutuhkan waktu (bisa jadi agak lama) karena tidak setiap waktu dapat bertemu dengan petugas kesehatan (bidan atau dokter). Problem lain yang dapat terjadi adalah para ibu hamil akan mengalami kesulitan untuk menyatukan informasi (aggregating information) yang didapatkan dari orang yang memiliki kompetensi (bidan dan dokter) dengan yang tidak kompeten (orang tua, saudara, atau teman). Oleh karena itu, beberapa problem tersebut pada akhirnya akan berisiko terjadi kesalahan dalam menginterpretasikan bahkan lebih jauh lagi untuk memanfaatkan informasi yang telah diperoleh.

Hasil penelitian yang disajikan pada Tabel 3 menunjukkan sebagian besar responden mempercayai informasi tentang kesehatan nifas, namun hanya $16,9 \%$ yang menyatakan memanfaatkannya meski hanya sebagian kecil. Para responden yang menyatakan tidak mempercayai informasi kesehatan nifas yang didapat memang sedikit (22\%). Namun, ternyata hampir sebagian dari kelompok ini tetap memanfaatkannya. Hasil ini menunjukkan terdapat kontradiksi antara tingkat kepercayaan terhadap informasi dengan keputusan memanfaatkan para ibu hamil yang menjadi responden. Temuan dari penelitian ini menunjukkan bahwa ada sekelompok ibu hamil yang dapat berada pada insecure condition (kondisi tidak aman) khususnya pada saat memasuki masa nifas karena salah menginterpretasikan bahkan memanfaatkan informasi kesehatan nifas yang diperoleh.

\section{SIMPULAN}

Berdasarkan hasil penelitian dapat disimpulkan bahwa literasi informasi para ibu hamil berstatus sosial menengah ke bawah di Kota Surabaya lebih dominan mencari informasi kesehatan nifas melalui orang lain. Kebanyakan dari para ibu hamil yang menjadi responden mempercayai informasi kesehatan nifas yang didapatkan dari sumber orang lain, namun tidak banyak yang memanfaatkan informasi tersebut. Ada kemungkinan kelompok responden ibu hamil berada dalam kondisi tidak aman (insecure condition) akibat kekeliruan menginterpretasikan informasi yang diperoleh dari orang lain.

\section{DAFTAR PUSTAKA}

Anders Haug, Frederik Zachariassen, D. van L. (2011) 'The Costs of Poor Data Quality', Journal of Industrial Engineering and Management, 4(2), pp. 168-193. doi: 10.3926/jiem.2011.v4n2.p168-193.

Cheng, C.-Y., Fowles, E. R. and Walker, L. O. (2006) 'Postpartum Maternal Health Care in the United States: A Critical Review', Journal of Perinatal Education, 15(3), pp. 34-42. doi: 10.1624/105812406X119002.

De Choudhury, M., Morris, M. R. and White, R. W. (2014) 'Seeking and Sharing Health 
Information Online', in Systems, C. '14 P. of the S. C. on H. F. in C. (ed.) Proceedings of the 32nd annual ACM conference on Human factors in computing systems - $\mathrm{CHI}$ '14. New York: CHI, pp. 1365-1376. doi: 10.1145/2556288.2557214.

Dalberg (2012) Women and the Web, Intel Corporation. United States: Intel Corporation. Available at: https://www.intel.com/content/dam/www/publ ic/us/en/documents/pdf/women-and-theweb.pdf (Accessed: 7 January 2018).

Ekawati and Haniah (2017) 'Pengetahuan Ibu Nifas Tentang Kunjungan Ulang Masa Nifas di Puskesmas Tepus 1 Kabupaten Gunungkidul', Jurnal Media IImu Kesehatan, 6(1), pp. 26-31. doi: https://doi.org/10.30989/mik.v6i1.208.

Kementerian Kesehatan Republik Indonesia (2016) Buku Kesehatan lbu dan Anak. Jakarta: Kementerian Kesehatan Republik Indonesia. Available at: http://www.depkes.go.id/article/view/1609150 0001/Buku-Kesehatan-Ibu-dan-Anak-Tahun2016.html.

Khafidzoh, A., Rahfiludin, M. Z. and Kartasurya, M. I. (2016) 'Hubungan Keikutsertaan Kelas Ibu Hamil dengan Perilaku Ibu dalam Perawatan Masa Nifas (Studi di Puskesmas Cepiring Kabupaten Kendal)', Jurnal Kesehatan Masyarakat (e-journal), 4(3), pp. 147-157. Available at: https://media.neliti.com/media/publications/1 8602-ID-hubungan-keikutsertaan-kelas-ibuhamil-dengan-perilaku-ibu-dalam-perawatanmasa.pdf.

Missiriya, S. (2016) 'Knowledge and Practice of Postnatal Mothers Regarding Personal Hygiene and Newborn Care', International Journal of Pharmaceutical Sciences, 40(1), pp. 89-93. doi: 10.22038/IJN.2013.692.

Mokhtar, I. A., Majid, S. and Foo, S. (2004) 'Measuring Information Literacy In Education', in Information, Learning, Innovation: Delivering Global Knowledge. Brunei: NTU, pp. 1-18. Available at: http://www.ntu.edu.sg/home/sfoo/publication s/2004/2004CILLLI_fmt.pdf.

Nan Xiao, Raj Sharman, H. R. Rao, S. U. (2014) 'Factors Influencing Online Health Information Search: an Empirical Analysis of a National Cancer-Related Survey', Decision Support System, 57, pp. 417-427. doi: 10.1016/j.dss.2012.10.047.

Nighat Sultana, B. T. (2015) 'Low Utilization of Postnatal Care: Searching The Window of Opportunity to Save Mothers and Newborns Lives in Islamabad Capital Territory, Pakistan', BMC Research Notes. BioMed Central, 8(1), pp. 1-5. doi: 10.1186/s13104015-1646-2.

Nymisha Chilukuri, Meredith West, Janice Lynn Henderson, Shari Lawson, Robert Ehsanipoor, Kathleen Costigan, Sarah Polk, W. B. (2015) 'Information and Communication Technology Use Among Low-Income Pregnant and Postpartum
Women by Race and Ethnicity: A CrossSectional Study', Journal of Medical Internet Research, 17(7), pp. 1-20. doi: 10.2196/jmir.3916.

Sulaeman, E. S., Murti, B. and Waryana, W. (2015) 'Peran Kepemimpinan, Modal Sosial, Akses Informasi serta Petugas dan Fasilitator Kesehatan dalam Pemberdayaan Masyarakat Bidang Kesehatan', Jurnal Kesehatan Masyarakat Nasional, 9(4), pp. 353-361. doi: 10.21109/kesmas.v9i4.749.

Tara Shah, S. P. (2016) 'Knowledge and Practice Regarding Postnatal Care among Mothers Residing In Selected Slum Area of Dharan, Nepal', International Journal of Health and Medicine, 1(1), pp. 1-4.

Y.P Rahayu, Sarkiah, N. D. U. (2016) 'Hubungan Motivasi Ibu dan Dukungan Keluarga dengan Kunjungan Nifas Lengkap di Wilayah Kerja Puskesmas Beruntung Raya Kota Banjarmasin', Jurnal Dinamika Kesehatan, 7(2), pp. 266-278. doi: 10.1007/s40304-0150072-z. 